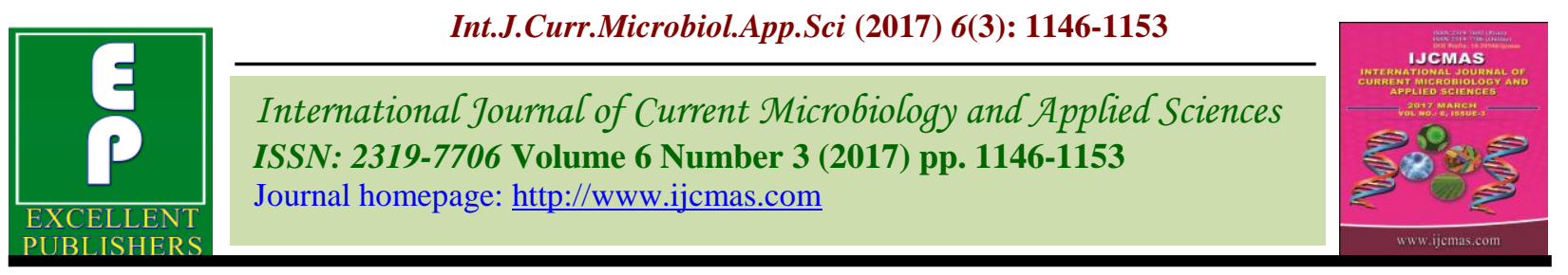

Original Research Article https://doi.org/10.20546/ijcmas.2017.603.133

\title{
Morphological and Cultural Studies of Sclerotium rolfsii Sacc. causing Foot Rot Disease of Tomato
}

\author{
Sahana N. Banakar*, V.B. Sanath Kumar and A.G. Thejesha \\ Department of Plant Pathology, College of agriculture, V. C Farm Mandya, \\ UAS, Bengaluru, India \\ *Corresponding author
}

\section{A B S T R A C T}

\begin{tabular}{|l|}
\hline Ke y w or d s \\
Sclerotium rolfsii, \\
$\begin{array}{l}\text { Foot rot, } \\
\text { Morphological } \\
\text { variability, } \\
\text { Cultural } \\
\text { variability. }\end{array}$ \\
\hline Article Info \\
\hline $\begin{array}{l}\text { Accepted: } \\
\text { 20 February } 2017 \\
\text { Available Online: } \\
\text { 10 March } 2017\end{array}$ \\
\hline
\end{tabular}

Morphological and cultural variability of $S$. rolfsii infecting tomato were studied on different solid and liquid media based on radial growth, topography, sclerotial number, diameter of sclerotia, test weight of sclerotial bodies and dry mycelial weight. Significant variability with reference to mycelial and sclerotial characters was observed on different media. This investigation revealed that the maximum mycelial growth was observed in Potato Dextrose Agar $(9 \mathrm{~cm})$ and more test weight $(262 \mathrm{mg})$ of sclerotial bodies was recorded in Sabouraud's dextrose agar. Cultural studies showed the maximum dry mycelial weight of fungus in potato dextrose broth $(750 \mathrm{mg}$ ) followed by oat meal broth $(663 \mathrm{mg})$.

\section{Introduction}

Tomato (Lycopersicon esculentum L.) is an important nutritive rich and warm season vegetable crop grown throughout the world. In the world, tomato is cultivated in an area of 4.8 million hectare with an annual production of 161.8 million tonnes (Anonymous, 2012). In India, it occupies an area of about 0.88 million hectares with the production of 18.22 million tonnes (Anonymous, 2013). In Karnataka it occupies an area of 0.05 million hectare with a production of 1.76 million tonnes (Anonymous, 2013). It suffers from number of fungal, bacterial, nematode and many viral diseases. Among the phytopathogenic fungi, disease caused by Sclerotium rolfsii, a soil borne fungi which

causes foot rot or collar rot of tomato is gaining a serious status. It is known to be pathogenic on nearly 500 plant species. The disease is also referred as Sclerotium blight, Sclerotium wilt, southern blight, southern stem rot and white mold which cause 55-95\% mortality of the crop at seedling stage under condusive conditions (Gurha and Dubey, 1982). S. rolfsii Sacc. is widely distributed in tropics, subtropics and also in warmer parts of temperate zone of the world. In India, it is wide spread in almost all the states and causing economic losses in many crops. The numerous reports from tropical and sub tropical areas of the world, coupled with the large number of hosts attacked by it indicate 
that, economic losses are substantial every year due to infection of $S$. rolfsii (Aycock, 1966).

Although, extreme variations in morphological characteristics have been noticed in worldwide collections of the pathogen (Koech et al., 1994 and Kumar et al., 1995) not much is known about the variations on different media. The objective of the present investigation was to study the variations regard to morphology of mycelium and sclerotia viz., colour, shape and size, number and test weight of sclerotia on different solid and liquid media.

\section{Materials and Methods}

\section{Isolation of the pathogen}

Isolation of the fungus was done by following standard tissue isolation technique from infected tomato plants. The fungal growth on the infected tissue was aseptically transferred to the PDA plates for growth and purification. Pure culture of the pathogen was transferred to PDA slants for further studies.

\section{Morphological variability}

The study comprises of 8 solid and liquid media (Table 1). Fifteen $\mathrm{ml}$ of each sterilised medium was poured into Petri plates. Mycelial disc from seven day old culture of the $S$. rolfsii was placed at the centre of the plate. Three replications were maintained at room temperature $\left(27 \pm 1^{\circ} \mathrm{C}\right)$ for three days and colony characters viz., diameter, pigmentation, radial growth and type of margin were recorded. To get matured sclerotial bodies, the cultures were further incubated up to thirty days. On each medium, diameter of ten sclerotial bodies per replication was recorded with the help of screw gauge and observations were statistically analysed. The total number of sclerotia produced per plate, test weight (100 sclerotial) and shape of sclerotia on individual media were also recorded.

\section{Cultural variability}

Twenty $\mathrm{ml}$ each of the liquid media was taken in $100 \mathrm{ml}$ conical flasks and sterilized in an autoclave at $121.6^{\circ} \mathrm{C}$ and 15 PSI for $15 \mathrm{~min}$. Five $\mathrm{mm}$ discs of seven day old culture were used for inoculation to each flask. Inoculated flasks were incubated at $27 \pm 1^{\circ} \mathrm{C}$ for 10 days. Each treatment was replicated thrice. After the incubation period, the mycelial mat was filtered through Whatman No. 42 filter paper discs. The mycelial mat on the filter paper was dried to a constant weight in an electrical oven at $50^{\circ} \mathrm{C}$, cooled in desiccators and weighed immediately on an analytical electrical balance. The weight of dry mycelium in each replication was recorded and the data were statistically analyzed.

\section{Results and Discussion}

Morphological characters of $S$. rolfsii on eight different solid media based on the characters like radial growth, mycelial characteristics, colony colour, shape and number of sclerotial bodies per plate and test weight of sclerotial bodies were studied.

The result revealed that the variation in colony diameter (Table 2 and Plate 1) on different media was found significant after 72 $\mathrm{h}$ of incubation. In Potato dextrose agar (PDA) maximum colony diameter $(9.0 \mathrm{~cm})$ was recorded after 48 hours of incubation whereas on oat meal agar maximum colony diameter $(9.0 \mathrm{~cm})$ was recorded after 72 hours of incubation. However, these two media were on par with each other. The minimum colony diameter $(3.4 \mathrm{~cm})$ was recorded on Sabouraud's Dextrose Agar (SDA) followed by Nutrient agar $(4.8 \mathrm{~cm})$. There was significant difference between media and time interval. 
With respect to colony colour, three types of colours were observed on different solid media (Table 3). Among the media viz., PDA, Kirchoff's agar, SDA, Hunsen's agar and tomato leaf extract showed pure white colonies, where as Richard's agar and nutrient agar showed dull white coloured colony. On oat meal agar cottony white coloured colony was observed. With regard to growth pattern, $S$. rolfsii showed compact growth on PDA and oat meal agar was recorded. On Kirchoff's agar and Hunsen's agar, it showed filamentous growth and on SDA and tomato leaf extract it was fluffy. However on nutrient agar colony growth was cloudy type. On most of the media mycelial margin was smooth except SDA and Kirchoff's agar which showed filamentous and serrated margin respectively. With respect to distribution of mycelial growth, $S$. rolfsii showed thick mycelial growth on PDA, oat meal agar and tomato leaf extract. However in Kirchoff's agar, SDA, Hunsen's agar it showed thin mycelia growth whereas in Richard's agar and nutrient agar showed irregular mycelial growth.

The sclerotial initiation started on eight days after incubation on tomato leaf extract and it was on $10^{\text {th }}$ day in case of PDA. On Hunsen's agar sclerotial initiated after $13^{\text {th }}$ day. Media viz., Kirchoff's agar and nutrient agar on $18^{\text {th }}$ day, whereas in oat meal agar and SDA on $20^{\text {th }}$ day after incubation (Table 4). However there was no sclerotial body production was recorded in Richard's agar (Plate 2). With regard to position of sclerotia, on three media i.e. PDA, oat meal agar and tomato leaf extract, sclerotia were distributed uniformly all over the plates. But in case of Kirchoff's agar, SDA, Hunsen's agar and nutrient agar sclerotial bodies were concentrated at the edges or periphery of the Petri plate.

With respect to shape of sclerotia, on most of the media $S$. rolfsii produced round sclerotial except SDA and tomato leaf extract in which it had produced irregular sclerotial bodies. Among all the media tested four types of colours were observed with respect to sclerotial colour. Sclerotial bodies were brown in colour on PDA, Hunsen's agar and tomato leaf extract where as dark brown colour was observed on oat meal agar and SDA. Light brown and very light brown colours were observed on Kirchoff's agar and nutrient agar respectively.

Table.1 List of media used to study the growth characters of Sclerotium rolfsii causing tomato foot rot disease

\begin{tabular}{|l|l|l|l|}
\hline \multicolumn{1}{|c|}{$\begin{array}{c}\text { SI. } \\
\text { No }\end{array}$} & \multicolumn{1}{|c|}{ Solid media } & \multicolumn{1}{c|}{ Liquid broth } & \multicolumn{1}{c|}{ Type of media } \\
\hline 1 & Potato dextrose agar (PDA) & Potato dextrose broth & Semi-synthetic \\
\hline 2 & Oat meal agar & Oat meal broth & Semi-synthetic \\
\hline 3 & Kirchoff's agar & Kirchoff's broth & Synthetic \\
\hline 4 & $\begin{array}{l}\text { Sabouraud's dextrose agar } \\
\text { (SDA) }\end{array}$ & $\begin{array}{l}\text { Sabouraud's dextrose } \\
\text { broth }\end{array}$ & Synthetic \\
\hline 5 & Hunsen's agar & Hunsen's broth & Synthetic \\
\hline 6 & Richard's agar & Richard's broth & Synthetic \\
\hline 7 & Nutrient agar & Nutrient broth & Synthetic \\
\hline 8 & Tomato leaf extract & $\begin{array}{l}\text { Tomato leaf extract } \\
\text { broth }\end{array}$ & Semi-synthetic \\
\hline
\end{tabular}


Table.2 Growth of S. rolfsii on different solid media

\begin{tabular}{|l|l|c|c|c|c|}
\hline $\begin{array}{c}\text { Treat } \\
\text { ments }\end{array}$ & \multicolumn{4}{|c|}{ Media } & \multicolumn{4}{|c|}{$\begin{array}{c}\text { Mean colony diameter(cm) (hours after } \\
\text { incubation) }\end{array}$} \\
\hline & & $\mathbf{2 4}$ & $\mathbf{4 8}$ & $\mathbf{7 2}$ & Mean \\
\hline $\mathrm{T}_{1}$ & Potato dextrose agar (PDA) & 3.8 & 9.0 & 9.0 & 7.22 \\
\hline $\mathrm{T}_{2}$ & Oat meal agar & 3.2 & 8.2 & 9.0 & 6.80 \\
\hline $\mathrm{T}_{3}$ & Kirchoff's agar & 2.4 & 3.8 & 5.1 & 3.76 \\
\hline $\mathrm{T}_{4}$ & Sabourauds dextrose agar (SDA) & 2.5 & 2.9 & 3.4 & 2.99 \\
\hline $\mathrm{T}_{5}$ & Hunsen's agar & 3.5 & 7.2 & 8.6 & 6.43 \\
\hline $\mathrm{T}_{6}$ & Richard's agar & 2.3 & 4.2 & 5.0 & 3.88 \\
\hline $\mathrm{T}_{7}$ & Nutrient agar & 1.7 & 3.1 & 4.8 & 3.20 \\
\hline $\mathrm{T}_{8}$ & Tomato leaf extract & 2.5 & 5.9 & 8.0 & 5.46 \\
\hline & SEm \pm & $\mathbf{0 . 0 7 6}$ & $\mathbf{0 . 2 1 3}$ & $\mathbf{0 . 0 1 5}$ & \\
\hline & C.D at 1\% & $\mathbf{0 . 2 2 8}$ & $\mathbf{0 . 6 3 8}$ & $\mathbf{0 . 0 4 9 5}$ & \\
\hline
\end{tabular}

Table.3 Colony characters of $S$. rolfsii on different solid media

\begin{tabular}{|c|c|c|c|c|c|}
\hline Treatments & Media & $\begin{array}{c}\text { Mycelia } \\
\text { colour }\end{array}$ & $\begin{array}{c}\text { Mycelia } \\
\text { margin }\end{array}$ & $\begin{array}{c}\text { Growth } \\
\text { pattern }\end{array}$ & $\begin{array}{c}\text { Distribution } \\
\text { of mycelia } \\
\text { growth }\end{array}$ \\
\hline $\mathrm{T}_{1}$ & $\begin{array}{c}\text { Potato dextrose } \\
\text { agar }\end{array}$ & Pure white & Smooth & Compact & Thick \\
\hline $\mathrm{T}_{2}$ & Oat meal agar & $\begin{array}{c}\text { Cottony } \\
\text { white }\end{array}$ & Smooth & Compact & Thick \\
\hline $\mathrm{T}_{3}$ & Kirchoff's agar & Pure white & Smooth & Filamentous & Thin \\
\hline $\mathrm{T}_{4}$ & $\begin{array}{c}\text { Sabouraud's } \\
\text { dextrose agar }\end{array}$ & Pure white & Filamentous & Fluffy & Thin \\
\hline $\mathrm{T}_{5}$ & $\begin{array}{c}\text { Hunsen's agar } \\
\mathrm{T}_{6}\end{array}$ & Pure white & Smooth & Filamentous & Thin \\
\hline $\mathrm{T}_{7}$ & $\begin{array}{c}\text { Rutrient agar } \\
\text { agar }\end{array}$ & Dull white & Smooth & Cloudy & Irregular \\
\hline $\mathrm{T}_{8}$ & $\begin{array}{c}\text { Tomato leaf } \\
\text { extract }\end{array}$ & Pure white & Smooth & Fluffy & Thick \\
\hline
\end{tabular}


Table.4 Sclerotial characters of $S$. rolfsii on different solid media

\begin{tabular}{|c|c|c|c|c|c|c|c|c|}
\hline Treatments & MEDIA & $\begin{array}{c}\text { Days to } \\
\text { sclerotial } \\
\text { initiation }\end{array}$ & $\begin{array}{c}\text { Distribution } \\
\text { over media }\end{array}$ & Shape & $\begin{array}{c}\text { Colour } \\
\text { and } \\
\text { texture }\end{array}$ & $\begin{array}{l}\text { Diameter } \\
(\mathbf{m m})\end{array}$ & $\begin{array}{c}\text { Test } \\
\text { weight } \\
(\mathrm{mg})(100 \\
\text { sclerotial } \\
\text { bodies }) \\
\end{array}$ & $\begin{array}{c}\text { No. } \\
\text { per } \\
\text { plate }\end{array}$ \\
\hline $\mathrm{T}_{1}$ & $\begin{array}{c}\text { Potato } \\
\text { dextrose agar }\end{array}$ & $10^{\text {th }}$ & All over & Round & Brown & 1.50 & 238 & 212 \\
\hline $\mathrm{T}_{2}$ & Oat meal agar & $20^{\text {th }}$ & All over & Round & $\begin{array}{c}\text { Dark } \\
\text { Brown }\end{array}$ & 1.70 & 131 & 205 \\
\hline $\mathrm{T}_{3}$ & $\begin{array}{c}\text { Kirchoff's } \\
\text { agar }\end{array}$ & $18^{\text {th }}$ & Periphery & Round & $\begin{array}{l}\text { Light } \\
\text { Brown }\end{array}$ & 1.60 & 91 & 59 \\
\hline $\mathrm{T}_{4}$ & $\begin{array}{l}\text { Sabouraud's } \\
\text { dextrose agar }\end{array}$ & $20^{\text {th }}$ & Periphery & Irregular & $\begin{array}{c}\text { Dark } \\
\text { Brown }\end{array}$ & 1.50 & 262 & 60 \\
\hline $\mathrm{T}_{5}$ & Hunsen's agar & $13^{\text {th }}$ & Periphery & Round & Brown & 1.50 & 92 & 48 \\
\hline $\mathrm{T}_{6}$ & Richard's agar & $*_{-}$ & - & - & - & - & - & - \\
\hline $\mathrm{T}_{7}$ & Nutrient agar & $18^{\text {th }}$ & Periphery & Round & $\begin{array}{l}\text { V.light } \\
\text { Brown }\end{array}$ & 0.11 & 56 & 45 \\
\hline \multirow[t]{3}{*}{$\mathrm{T}_{8}$} & $\begin{array}{c}\text { Tomato leaf } \\
\text { extract }\end{array}$ & $8^{\text {th }}$ & All over & Irregular & Brown & 0.12 & 121 & 198 \\
\hline & SEm \pm & & & & & 0.221 & 1.38 & 1.00 \\
\hline & C.D at $1 \%$ & & & & & 0.662 & 4.15 & 4.131 \\
\hline
\end{tabular}

Note: *- Sclerotial bodies were not produced 
Table.5 Cultural chararacters (dry mycelia weight, no. of sclerotia/flask, colour of sclerotia) of $S$. rolfsii on different liquid media

\begin{tabular}{|c|c|c|c|c|}
\hline S.No & Name of the broth & $\begin{array}{c}\text { Dry mycelia } \\
\text { weight }(\mathbf{m g})\end{array}$ & $\begin{array}{c}\text { No. of } \\
\text { sclerotia/flask }\end{array}$ & $\begin{array}{c}\text { Colour of } \\
\text { sclerotia }\end{array}$ \\
\hline 1 & Potato dextrose broth & 750 & 350 & Brown \\
\hline 2 & Oat meal broth & 663 & 310 & Dark Brown \\
\hline 3 & Kirchoff's broth & 435 & 96 & Light Brown \\
\hline 4 & Sabouraud's broth & 203 & 120 & Dark Brown \\
\hline 5 & Hunsen's broth & 365 & 67 & Brown \\
\hline 6 & Richard's broth & 244 & 0 & No sclerotia \\
\hline 7 & Nutrient broth & 10 & 15 & V.light Brown \\
\hline 8 & Tomato leaf extract broth & 550 & 295 & Brown \\
\hline & SEm \pm & $\mathbf{6 . 4 4 4}$ & $\mathbf{3 . 8 8 0}$ & \\
\hline & C.D at 1\% & $\mathbf{1 9 . 3 1 0}$ & $\mathbf{1 1 . 6 3 2}$ & \\
\hline
\end{tabular}

Plate.1 Growth of Sclerotium rolfsii on different solid media

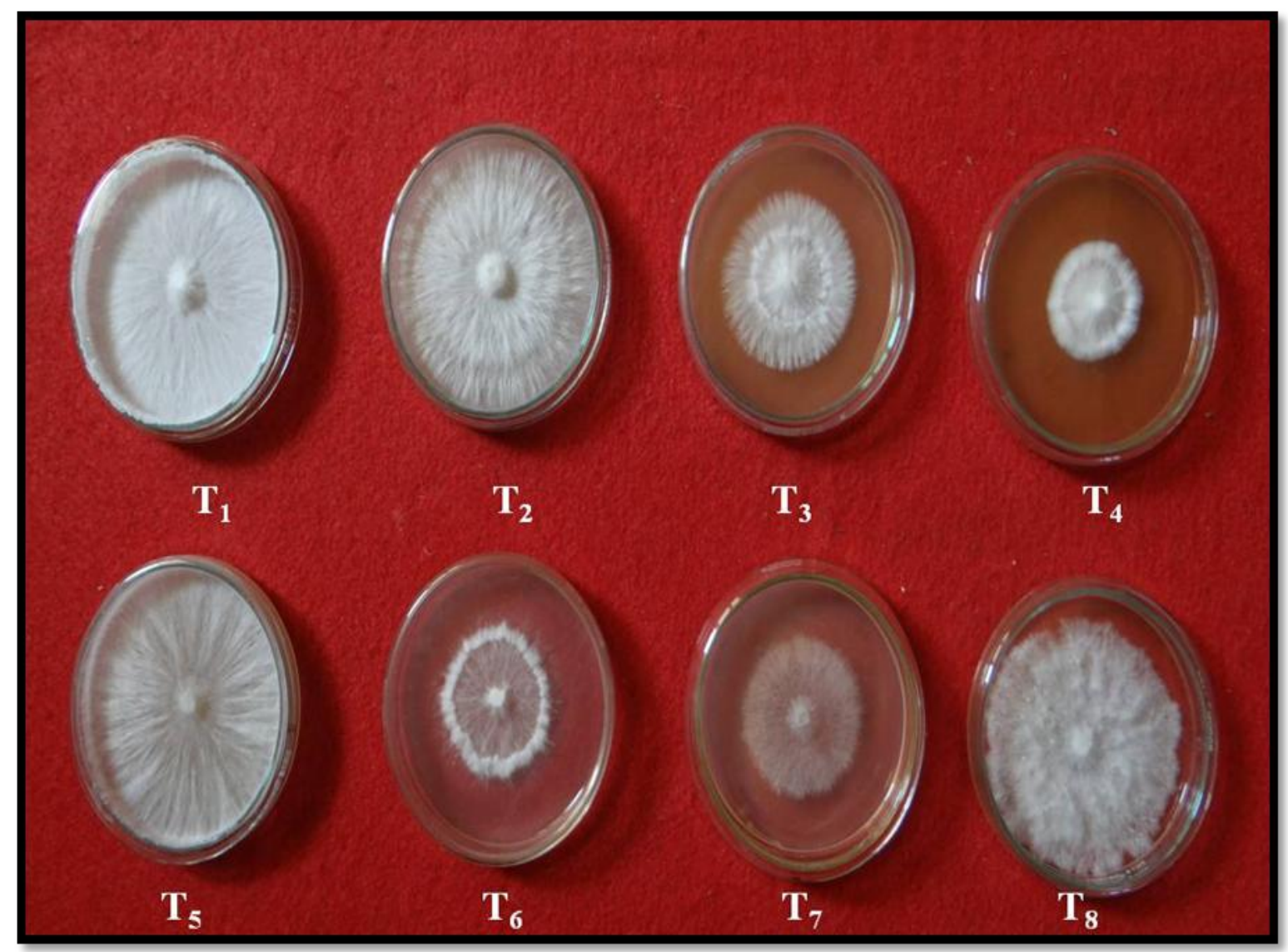

\section{Legend:}

$\mathbf{T}_{\mathbf{1}}$ : Potato dextrose agar; $\mathbf{T}_{2}$ : Oat meal agar; $\mathbf{T}_{\mathbf{3}}$ : Kirchoff's agar; $\mathbf{T}_{\mathbf{4}}$ : Sabourauds dextrose agar; $\mathbf{T}_{5}$ : Hunsen's agar; $\mathbf{T}_{6}:$ Richard's agar; $\mathbf{T}_{\mathbf{7}}$ : Nutrient agar agar; $\mathbf{T}_{\mathbf{8}}:$ Tomato leaf extract 
Plate.2 Production of sclerotial bodies of Sclerotium rolfsii on different solid media

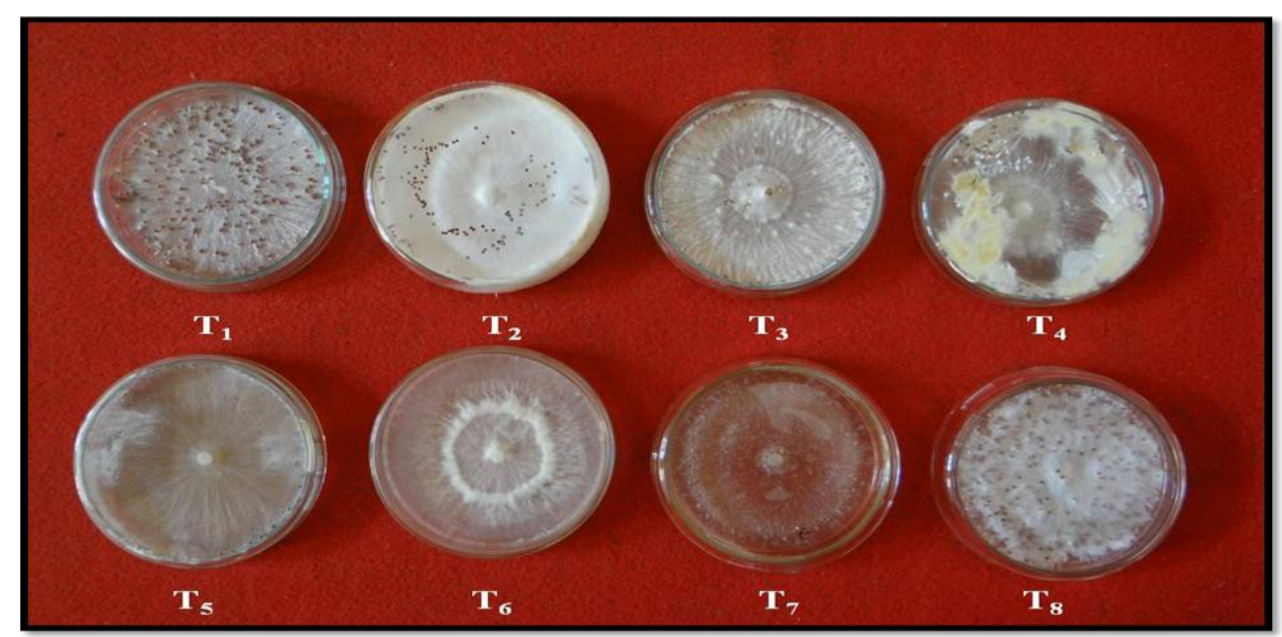

Legend:

$\mathbf{T}_{1}$ : Potato dextrose agar; $\mathbf{T}_{2}$ : Oat meal agar; $\mathbf{T}_{\mathbf{3}}$ : Kirchoff's agar; $\mathbf{T}_{\mathbf{4}}$ : Sabourauds dextrose agar; $\mathbf{T}_{\mathbf{5}}$ : Hunsen's agar; $\mathbf{T}_{\mathbf{6}}$ : Richard's agar; $\mathbf{T}_{\mathbf{7}}$ : Nutrient agar agar; $\mathbf{T}_{\mathbf{8}}$ : Tomato leaf extract

Plate.3 Growth of Sclerotium rolfsii on liquid media

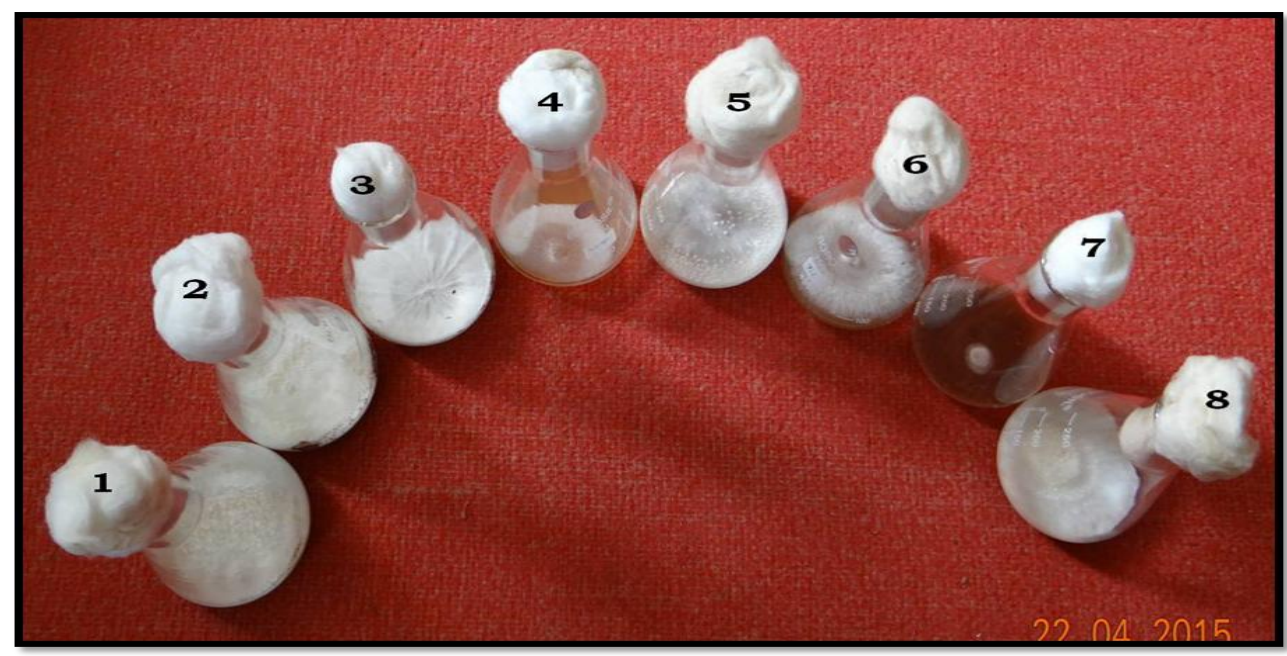

\section{Legend:}

1: Potato dextrose broth; 2: Oat meal broth; 3: Kirchoff's broth; 4: Sabourauds dextrose broth; 5: Hunsen's broth; 6: Richard's broth; 7: Nutrient broth; 8: Tomato leaf broth

The variations in size of sclerotial bodies of different media were recorded. On oat meal agar biggest sclerotial bodies of $1.7 \mathrm{~mm}$ diameter were produced followed by Kirchoff's agar $(1.6 \mathrm{~mm})$. Smaller size of sclerotial bodies were recorded on nutrient agar $(0.11 \mathrm{~mm}$ diameter) followed by tomato leaf extract $(0.12 \mathrm{~mm}$ diameter $)$.

The test weight (weight of 100 sclerotial bodies) of sclerotial bodies on all the solid media varied significantly. Maximum test weight of sclerotial bodies was recorded in SDA $(262 \mathrm{mg})$ followed by PDA (238 mg). Minimum test weight was recorded in nutrient agar medium $(56 \mathrm{mg})$. The density of sclerotial bodies per Petri plate revealed that there was a significant variation among the different solid media. On PDA more densely populated sclerotial bodies (212 no./plate) were recorded which was followed by oat meal agar (205 no./plate). However no sclerotial body 
production was recorded in Richard's agar. Cultural characters like dry mycelia weight, number of sclerotia/flask, colour of sclerotia) of $S$. rolfsii were studied on eight different liquid media (Table 5 and Plate 3). The results showed that the synthetic media produce less mycelial weight and number of sclerotia/flask, compared to semi synthetic media. Maximum dry mycelial weight of fungus was obtained in potato dextrose broth (750 $\mathrm{mg}$ ) followed by oat meal broth $(663 \mathrm{mg})$ and host leaf extract $(550 \mathrm{mg})$. Among the synthetic media tested, maximum mycelial weight of the fungus was recorded in Kirchoff's broth (435 mg) followed by Hunsen's broth $(365 \mathrm{mg}$ ) and Richard's broth (244 mg). Least mycelial dry weight of the fungus was recorded in nutrient broth (10 mg).

Among the semi synthetic media, highest number of sclerotial bodies were produced in potato dextrose broth (350 no./flask) and among the synthetic media, Sabouraud's broth (120 no./flask) produced more sclerotial bodies. Less sclerotial bodies were recorded in nutrient broth (15 no./flask). The present study is in line with many workers (Lingaraju (1977), Prabhu (2003), Basamma (2008) and Manu (2012) who had reported that the morphology of mycelium, number sclerotiaand morphology of sclerotia produced, varied in different media depends on nutritional factors. The present finding strongly suggest that the there is a morphological and cultural variation on different solid and liquid media.

\section{References}

Anonymous. 2012. FAOSTAT: Production crop 2012 data.

Anonymous. 2013. National Horticulture Mission, 3rd January to 12th January, pp. 10 .
Anonymous. 2013. Indian horticulture database. MOA. 1-301. pp.

Aycock, R., 1966. Stem rot and other diseases caused by $S$. rolfsii. North Carolina Agricultural Experimental Station, Technical Bull., 174: 202.

Basamma. 2008. Integrated management of Sclerotium wilt of potato caused by Sclerotium rolfsii Sacc. M. Sc. (Agri.) Thesis, Univ. Agric. Sci., Dharwad, 113. pp.

Dominique, B. 2012. A colour handbook of tomato diseases. Identification, biology and control. Manson publishing Ltd., 688. pp.

Gurha, S.N. and Dubey, R.S. 1982. Occurrence of possible sources of resistance in chickpea (Cicer arietinum L.) against Sclerotium rolfsii Sacc. Madras Agric. J., 70: 63-64.

Jabbar Sab. 2013. Studies on collar rot of chick pea caused by Sclerotium rolfsii Sacc. M. Sc. (Agri.) Thesis, Univ. Agric. Sci., Bengaluru.

Koech, J.K., Lewis, B. and Mithem, R. 1994. Pathogenic variation in isolates of Plasmodiophora brassicae on Brassica spp. Indian J. Pl. Patho., 12: 5-9.

Kumar, S., Thind, T.S. and Mohanchander. 1995. Morphogenic and pathogenic variations in Gloeosporium amoelophagum. Indian Phytopathol., 48: 331-334.

Lingaraju, S. 1977. Studies on Sclerotium rolfsii Sacc. with respect to the survival in soil. $M$. Sc. (Agri.) Thesis, Univ. Agric. Sci., Bangalore, 61. pp.

Manu, T.G. 2012. Studies on Sclerotium rolfsii (Sacc.) causing foot rot disease on finger millet M.Sc. (Agri.) Thesis, Univ. Agric. Sci., Bangalore, 76. pp.

Prabhu, H.V. 2003. Studies on collar rot of soybean caused Sclerotium rolfsii Sacc. $M$. Sc. (Agri.) Thesis, Univ. of Agric. Sci., Dharwad.

\section{How to cite this article:}

Sahana N. Banakar, V.B. Sanath Kumar and Thejesha, A.G. 2017. Morphological and Cultural Studies of Sclerotium rolfsii Sacc. causing Foot Rot Disease of Tomato. Int.J.Curr.Microbiol.App.Sci. 6(3): 1146-1153. doi: https://doi.org/10.20546/ijcmas.2017.603.133 